\title{
What Triggers Teacher Research Engagement and Sustainability in a Higher Education Context in Turkey?
}

\author{
Vildan Sakarkaya \\ School of Foreign Languages, Izmir Kâtip Çelebi University, Izmir, Turkey \\ ORCID: 0000-0003-0572-5388
}

\author{
Nilay T. Bümen* \\ Faculty of Education, Ege University, Izmir, Turkey \\ ORCID: 0000-0003-1891-6589
}

\section{Article history}

\section{Received:}

23.04.2021

Received in revised form: 05.07.2021

Accepted:

28.07.2021

Key words:

Teacher research in professional development, Teacher research engagement, The sustainability of teacher research
Despite its increasing popularity as a continuous professional development tool in ELT contexts, why teacher research remains as a minority activity and whether or how its impacts persist over time still require detailed exploration. In this mixed-methods case study of university instructors in Turkey, we address the questions of teacher research engagement and sustainability of its impacts. The study started with a relatively larger group $(n=33)$, and then gradually narrowed into three sub-groups to gain an in-depth understanding of the case. Two questionnaires consisting of closed and open-ended questions and interviews carried out with semi-structured forms have been used as data collection tools. The qualitative data have been analyzed by content analysis, while frequency analysis has been carried out for the quantitative data. Findings reveal that expert support and colleagues with research experience trigger teacher research engagement, whereas limitations in institutional support and instructors' awareness of teacher research and economic matters contribute to the most prevalent barrier to teacher research viz. lack of time. Moreover, instructors feel more motivated and confident, research-oriented four years after their teacher research projects. We argue that positive experience with context-related research projects and dissemination of research results in various forms facilitate the sustainability of those impacts and efforts to engage in new projects, while constraints in time and institutional support hinder these.

\section{Introduction}

Because of being one of the requirements for higher level, better-paid jobs, English has a very high status in Turkey (Dogancay-Aktuna \& Kiziltepe, 2005); therefore, many universities offer their students English-medium or mixed medium Turkish-English under-graduate programmes and the number continues to increase (British Council, 2015). As students are required to demonstrate a certain proficiency in

\footnotetext{
* Correspondency: nilay.bumen@ege.edu.tr
} 
English before starting their undergraduate studies, universities provide them with an English preparatory programme through Schools of Foreign Languages and this makes English Language Teaching (ELT) an important national activity (Borg, 2015a). However, it is asserted that the English language proficiency level of students is inadequate to support their English medium instruction programmes at universities (British Council, 2015; Çelik, Bayraktar-Cepni \& İlyas, 2013). Moreover, despite having high proficiency levels in English, language instructors are criticized for being incapable of creating teaching environments in which students are active and participate lessons using and exploring the language (British Council, 2015).

Borg (2015a) argues that in the demanding language teaching context at Turkish universities (characterized by certain pressures created by the need to support a large number of students having largely instrumental goals like getting into their faculties), the needs of instructors and, especially, the important role of continuous professional development (CPD) can be easily overlooked. In this context, recently, a tendency to conduct teacher research (TR) as part of their professional development (PD) activities has been observed among ELT instructors. Instructor researchers coming together at the conferences organized especially with the initiative of some foundation universities have been disseminating their findings and sharing ideas (Burns, Dikilitaş, Smith \& Wyatt, 2017; Dikilitaş, Smith \& Trotman, 2015; Dikilitaş, Wyatt \& Bullock, 2016). Also, the number of studies justifying that ELT teachers and instructors benefit TR in a variety of ways has increased (Atay, 2008; Cabaroğlu, 2014; Dikilitaş, 2016; Kayaoğlu, 2015; Trotman, 2015; Wyatt \& Dikilitaş, 2015). Nevertheless, most of these studies are either graduate thesis or conducted by the instructors of some foundation universities. Likewise, Borg $(2006$; 2010) states that TR remains largely a minority activity in the field of language teaching, and it is a prerequisite to analyse the conditions that facilitate TR. In this context, why TR is not a widespread activity adopted by language teachers, the potential of TR as a sustainable PD activity and the factors enabling TR thrive stand out as topics requiring in-depth analysis.

Moreover, although it has been observed that TR has a positive impact on teachers, students and institutions (Atay, 2008; Cabaroğlu, 2014; Dikilitaş, 2016; Trotman, 2015; Wyatt \& Dikilitaş, 2015), Borg and Sanchez (2015) states that it is criticized for the reliability of the evidence that is available since much of it comes from teachers themselves either in written or oral feedback or through research reports written at the end of a TR course (i.e. Burns \& Edwards, 2014; Gao \& Chow, 2012; Kayaoğlu, 2015; Smith, Connelly \& Robelledo, 2014; Yuan \& Lee, 2014; Wang \& Zhang, 2014; Wyatt \& Dikilitaş, 2014). Also, there are a limited number of studies (Edwards \& Burns, 2016; Yuan \& Lee, 2014) which question whether teachers' efforts to engage in research and its immediate positive effects are sustained over time and if so, how they are sustained.

This study addresses this issue by focusing on a specific context, in a country which does not have any study on this issue. We believed that identifying all these factors facilitating and hindering TR engagement and affecting the sustainability of positive impacts of TR was to provide us with valuable insight to promote TR and get rid of the barriers. The aim of this three-phased mixed-methods case study conducted with four study groups was to identify the factors that affect TR engagement and its sustainability. The research questions we investigated are: 
(1) What perceptions and experiences concerning TR do the participants (with / without TR experience) have?

(a) What made the participants engage into TR?

(b) Why did not the participants consider engaging into TR?

(2) Are there any perceived sustained impacts of previous TR projects on the participants? If so, what are those?

(3) What factors affected the sustainability of the impacts of TR?

We believe that the study may respond to Borg's (2015a) call, contribute to the engagement of a wider group of instructors into TR and enable TR to become a sustainable part of the ELT profession by providing us with a substantial number of indepth findings in a specific context. In light of these findings, educators from different countries may develop a deeper and better understanding of TR engagement and sustainability in different contexts. Those findings might help to suggest some solutions to overcome the barriers to a wider research engagement among teachers. Thus, the quality of instruction might be improved by providing ELT instructors with an opportunity to make informed decisions about their in-class practices, which will allow a nation-wide improvement in student performances in prep classes at universities in Turkey.

\section{Literature review}

TR, which is based on the combination of scientific knowledge and knowledge from practice, is considered as a powerful form of PD for teachers and carrying out a systematic inquiry about their practices has similar motives with the principles of CPD and the number of studies on TR has increased dramatically in China (Yuan, Sun \& Teng, 2016; Wang \& Zhang, 2014; Gao \& Chow, 2012), USA (Ado, 2013; HahsVaughn \& Yanowitz, 2009), Australia (Burns \& Edwards, 2014; Edwards \& Burns, 2016), Argentina (Banegas, Pavese, Velázquez \& Vélez, 2013), Finland (Niemi \& Nevgi, 2014) and Chili (Rebolledo, 2013; Smith, Connelly \& Robelledo, 2014). It has been found out that teachers become more learner-centred, more active, and autonomous in both teaching and research (Wang \& Zhang, 2016); professional competencies of teachers have increased (Niemi \& Nevgi, 2014), student performances have improved with the increase in the motivation and autonomy of teachers (Banegas et al., 2013).

Some studies also investigate why TR is still not a widespread activity, which only takes place within the context of formal programmes of study. Teachers' conceptions of their role and of research and lack of collegial and institutional support (Borg, 2010; Borg \& Sanchez, 2015), limitations in research skills, inflexible school programme and students' negative attitudes towards their research work (Yuan, Sun \& Teng, 2016) have been identified as demotivating factors to engage in research. Wang and Zhang (2014) observed that their participants passed through three developmental stages throughout their research processes and realized that despite the eagerness and excitement of teacher researchers at the beginning of their projects, the commitment required, difficulties experienced throughout the process and time pressure led to some dropouts, but realized that those teachers who followed each training session conscientiously and completed each of the project tasks seemed to have gained the most.

The sustainability of short-term impacts of TR is also a crucial point since without long 
term impact, we may have a 'win the battle, [but] lose the war' (Fullan, 2006). It is important to build something that will stay with teachers throughout their careers. However, there are very few studies investigating the ongoing impact of TR. In one of these studies, it was identified that the perceived impact was being sustained over the years following the completion of research projects and they became more confident, reflective and flexible in their approach to teaching, more research-oriented and more connected to their students (Edwards \& Burns, 2016). The factors that ease the sustainability of those benefits is another topic that needs more investigation (Edwards \& Burns, 2016). As Allwright (1997), states 'without sustainability nothing of value is going to be happening in the long term' (p. 369), so dropping out of research projects owing to some experienced difficulties will create neither short nor long term benefits (Borg \& Sanchez, 2015). Therefore, how teachers experience the research process (the difficulties and support mechanism) is also significant for the sustainability of both short-term effects and teachers' efforts to involve in new projects. Professional networks with colleagues, time, improvement in student performances, recognition and approval by colleagues and managers as a result of making their research results public are identified as motivating factors to involve in new projects (Senese, 2000). Other factors that help sustain the impact are support from educational leaders and university researchers to provide opportunities and incentives for teachers to initiate new projects (Yuan, Sun \& Teng, 2016), giving teachers autonomy to experiment with innovative ideas and allowing flexibility in their work schedule (Yuan \& Lee, 2014), non-academic alternative dissemination methods for research reports (Rebolledo, 2013), administrators creating and sustaining a supportive school environment (Hahs-Vaughn \& Yanowitz, 2009).

When the studies in Turkey are examined, it is seen that TR is clearly not a widespread activity, either and occur mostly within the context of degree programmes. Despite this, similar to international trends, there are studies highlighting TR as a powerful and significant PD activity (Akyazı, 2016; Atay, 2008; Cabaroğlu, 2014; Kayaoğlu, 2015). In those, the barriers to TR becoming a widespread activity are identified as misconceptions with TR (Borg, 2007) and time constraints (Borg, 2007; Kutlay, 2013). However, a study investigating these topics and the sustained effects of TR and factors helping the sustainability of these benefits in a specific context was not available.

\section{Method}

In this study, mixed-methods case study design with a convergent approach was adopted to obtain in-depth and complementary data to understand the case thoroughly. Within this type of design, both quantitative and qualitative data are collected concurrently, and the results are merged to examine the case(s) (Creswell \& Plano Clark, 2018, p.172, 188).

\section{Study Context}

The study was conducted at a 10-year-old state university in Turkey, where the medium of instruction is mostly $100 \%$ English. The School of Foreign Languages (SFL) has 40 instructors whose schedules include 18-24 hours of teaching and some other administrative tasks. In the seminars organized by the Professional Development Unit (PDU), instructors are introduced to various types of PD and encouraged to adopt one that suits them including TR. In 2013, a group of nine instructors came together to conduct individual TR projects with the guidance of the head of PDU who scaffolded 
the process with weekly tutorials with the support of an experienced colleague in supervising research studies at a nearby university. Five instructors completed the process and presented their findings at a conference and published them (Dikilitaş, Smith \& Trotman, 2015). The following year, a new group of six instructors, three of which were also in the previous year's group, came together for new individual TR projects. Eventually, findings of four TR projects were presented at an in-house conference by four instructors, two of which were also in the previous year's TR group.

\section{Participants and procedures}

The study started with a relatively larger group $(n=33)$, and then gradually narrowed into sub-groups to gain an in-depth understanding of the case. We formed four study groups with different sampling methods to collect comprehensive data for each research question (see Table 1). As Patton (1999) suggested, the triangulation of data sources as a way to strengthen validity, there were 33 participants in phase 1 , nine in phase 2, and four in phase 3 . In the first phase, we tried to reach all the instructors in the SFL and the characteristics of Study Group 1 (SG1) are illustrated in Table 2.

Table 1. Phases, study groups, sampling methods, research questions \& data collection

\begin{tabular}{lllll}
\hline Phases & Study groups & Sampling methods & Research questions & Data collection \\
\hline Phase 1 & 1 & Maximum variation & $1 \mathrm{a} \& 1 \mathrm{~b}$ & Questionnaire 1 \\
Phase 2 & 2,3 & Homogeneous & $1 \mathrm{a} \& 1 \mathrm{~b}$ & Interviews \\
Phase 3 & 4 & Criterion & $2 \& 3$ & Questionnaire 2 \& \\
& & & Interviews \\
\hline
\end{tabular}

Table 2. The Characteristics of Study Group 1

\begin{tabular}{ll}
\hline Variable & $\mathrm{n}$ \\
\hline Years of teaching & 0 \\
$0-4$ years & 15 \\
5-9 years & 13 \\
10-14 years & 3 \\
15-19 years & 2 \\
20-24 years & \\
Length of service in SFL & 6 \\
$0-1$ year & 5 \\
2-3 years & 22 \\
4-5 years & \\
Education level & 12 \\
BA & 16 \\
MA & 4 \\
PhD & \\
Field of study & 16 \\
ELT & 6 \\
Literature & 1 \\
Philology & 2 \\
Other & 16 \\
Educational sciences & 5 \\
Translation & 3 \\
TR experience & \\
Yes & \\
In SFL & 7 \\
Not in SFL & 5 \\
No & 21 \\
\hline &
\end{tabular}

We formed two other study subgroups (SG2: participants with TR experience \& SG3: participants with no TR experience) with homogeneous sampling considering the 
questionnaire 1 results: SG2 (involving six instructors who conducted TR during their 4-5 years of teaching experience at the institution) \& SG3 (involving three instructors with no TR experience before and during their 4-5 years of teaching experience at the institution), which is a smaller one because of the limited number of instructors who agreed to participate in the interviews. The characteristics of these groups are in Table 3. In the last phase, Study Group 4 (SG4) is formed with a criterion sampling method and they (P1, P13, P28 \& P33 in Table 3) were chosen from SG2. The criterion here was to have conducted TR and presented/ published in the years 2013-2014.

Table 3. The Characteristics of Study Group $2(n=6)$ and Study Group $3(n=3)$

\begin{tabular}{|c|c|c|c|c|}
\hline Groups & Participant & $\begin{array}{l}\text { Years of } \\
\text { teaching }\end{array}$ & $\begin{array}{l}\text { Education } \\
\text { level }\end{array}$ & Topics of TR projects \\
\hline \multirow{6}{*}{ SG2 } & P1 & $10-14$ & BA & Enhancing a learning-centred classroom \\
\hline & P13 & $5-9$ & BA & Creating a learner-centred classroom environment \\
\hline & P16 & $5-9$ & MA & $\begin{array}{l}\text { Raising students' intercultural awareness with } \\
\text { poetry }\end{array}$ \\
\hline & $\mathrm{P} 28$ & $20-24$ & MA & $\begin{array}{l}\text { Developing error-correction in teaching } \\
\text { pronunciation }\end{array}$ \\
\hline & P33 & $5-9$ & MA & $\begin{array}{l}\text { Student preferences for feedback on their written } \\
\text { work }\end{array}$ \\
\hline & P34* & $10-14$ & MA & $\begin{array}{l}\text { Student preferences for feedback on their written } \\
\text { work }\end{array}$ \\
\hline \multirow{3}{*}{ SG3 } & P4 & $5-9$ & BA & \\
\hline & P5 & $10-14$ & $\mathrm{BA}$ & \\
\hline & P30 & $10-14$ & MA & \\
\hline
\end{tabular}

\section{Data sources}

In the study, for internal validity, multiple data collection tools were used to collect data. We started the data collection process with Questionnaire 1 (Q1) called Questionnaire on factors affecting TR use in PD which includes closed and open-ended questions. The closed-ended part is for the instructors with no TR experience and prepared using Borg's (2010, p. 409) list on the barriers to TR. The open-ended part is for the instructors with TR experience and investigates what made them do TR. Having obtained the required informed consent of the institution and participants, in June 2017; the questionnaires were given to 37 of 40 instructors of SFL, 33 of which agreed to answer them.

In the second phase of the study, two separate interview guides were created for the participants who conducted and did not conduct TR as part of their PD (see Appendix 1 $\&$ 2). The interviews were conducted between 8-30 June 2017 with separate sessions. The participants were given verbal information about the purpose of the research, its importance and how to use the data, and informed consent was obtained.

Next, Questionnaire 2 (Q2) called Questionnaire on sustained effects of TR was used. We took Edwards' (2016) study as a model and tried to follow her steps to prepare our questionnaire: an analysis of five research reports presented in IATEFL Research SIG (ReSIG) conference in Izmir in June 2014 and published in Teachers Researchers in Action (Dikilitaş, Smith \& Trotman, 2015) was conducted. Those reports include reflection parts on the impacts of their TR process. Following a content analysis of these parts, we obtained a list of nine immediate impacts perceived by the instructors. These 
impacts were also compared with Trotman's (2015) findings, a study on the research processes of these instructors and the impact perceived by them. We used these to prepare our Q2 where they were first asked to assess whether they had experienced those impacts and to what extent on a Likert style and then provide more detail about why (not) / how those were sustained over time using open-ended questions. For the last phase of the study, in the semi-structured interviews, the participants were asked to provide more and in-depth data concerning the sustained impacts of TR and the factors affecting them.

\section{Data analysis and validation}

After the frequency counts of the quantitative data from the questionnaires were conducted, the qualitative data was prepared for analysis. Identifying details of interviewees were kept confidential by assigning new IDs like P1, P2 ...etc. The process started with the exploration of data by multiple readings through the transcripts. Using a code list generated throughout the literature review for the study, codes were assigned to specific parts of the data. Meanwhile, some codes that emerged during the analysis were also included in the code list and some were deleted (see Appendix 3). The process repeated multiple times (Strauss \& Corbin, 1990) and it is shown in Appendix 4 with an example of the coding process of the qualitative data set. After the cross-analysis of the questionnaire data with interview transcriptions, the most significant codes are identified, and similar ones were aggregated together to develop themes (Creswell \& Plano Clark, 2018). This process was repeated multiple times to evaluate the internal consistency of the codes under each theme.

Some validation strategies suggested by Creswell and Plano Clark (2018, p.312) were adopted throughout the study: we triangulated our data using multiple data collection tools and study groups. Coded interview transcriptions were sent to the participants to be checked whether they are an accurate reflection of their experiences. Also, besides being the co-author of the study, the second researcher, who has more research experience served as a peer examiner throughout the research process to minimize the effect of possible bias the first researcher might have because of her collegial and personal relationships with the participants and her quite positive attitude toward and experience with TR. Besides, the consistency of the codes and themes with the data was checked by the second researcher.

\section{Findings}

\section{Participants' perspectives on and experiences of TR engagement}

\section{Reasons for conducting TR}

The triggering factors to conduct TR are categorized under three main themes: instructor attributes, project features and workplace conditions.

Instructor attributes. All the participants who conducted TR before were found out to have positive attitudes and a need for PD. For instance, when they are asked why they conducted TR, P22 wrote that she did it to learn useful things to improve her students' success. Two others answered that like this: 
It was something voluntary. Since I already wanted to do something like this and also because I give importance to such things, I wanted to do it. (P13, interview)

I just wanted to improve myself by doing research on [...], which I have a strong passion for teaching. (P33, questionnaire)

Project features. We found out that all the TR projects conducted by the participants are voluntary and relevant to their professional goals and specific classroom concerns and conducted to find solutions to some problems they face in their teaching context. When describing the dialogue with the teacher trainer, one participant stated that she participated in the process willingly without being forced:

He asked me if I wanted to do TR. But, of course, nobody forced me. He asked me what I wanted to study. It was a kind of guidance. He tries to guide you to study something you are interested. (P16, interview)

Other teachers mentioned that they conducted TR to find solutions to some problems they face in their teaching context:

I conducted action research to deal with the problems in my class and to develop new instructional techniques. (P23, questionnaire)

[...] It was my teacher talking time...It was too long. When I realized this, I decided to research designing lessons in which I can engage more students into activities in class and increase student talking time while minimizing mine. (P13, interview)

Workplace conditions. We identified two subthemes triggering participants to engage in TR: colleagues with former TR experience or with ongoing postgraduate studies and the guidance and support of PDU coordinator. The mentoring style is one of the important factors that may affect the teachers' engagement in TR research:

When I first started working here, I saw that some instructors had done TR and published them or presented them at conferences. This was very motivating for me. I hadn't done anything like this except for my master's thesis. (P33, interview)

Our PDU coordinator, who runs TR programme, motivated us to conduct TR. (P24, questionnaire)

Our PDU coordinator helped us a lot. He was with us in every stage. Whenever we were puzzled and felt stuck, he was there to help us find a way out or find someone else to guide us to light. Thanks to them I never felt overwhelmed by the process. (P28, interview)

\section{Reasons for not conducting TR}

Table 4 illustrates the cross-analysis of the qualitative and quantitative data from Q1 and interviews. We organized data under three themes: workplace conditions, limitations in instructors' awareness, beliefs, skills and knowledge on TR and economic 
matters. We found out that those together constitute the most-mentioned barrier to TR, lack of time.

\section{Sustained impact of TR perceived by the instructors}

The cross-analysis of the data from questionnaires and interviews are illustrated in Table 5. The joint display showed that TR had a considerable impact on the participants, and it was sustained over four years following their engagement with TR in 2013 until 2017, when the data was collected. 
Table 4. The reasons for not conducting TR based on quantitative and qualitative data

\begin{tabular}{|c|c|c|c|}
\hline $\begin{array}{l}\text { Reasons related } \\
\text { to... }\end{array}$ & Items in Q1 & $\mathrm{f}^{*}$ & Quotes from interviews \\
\hline \multirow[t]{6}{*}{$\begin{array}{l}\text { Workplace } \\
\text { conditions }\end{array}$} & $\begin{array}{l}\text { I have other administrative responsibilities at school } \\
\text { besides teaching. }\end{array}$ & 15 & $\begin{array}{l}\text { "[...] when you have to teach for long hours and have other responsibilities to fulfil at school, you } \\
\text { may not have time to do it [TR]. And you may not be willing to work overtime at home, either." (P30) }\end{array}$ \\
\hline & My teaching workload is too heavy. & 12 & $\begin{array}{l}\text { "I think the pacing is very loaded and brisk. It might have been good [to conduct TR], but I need less } \\
\text { workload for this." (P10) }\end{array}$ \\
\hline & No expert support is available to guide research. & 11 & "I really need support from my colleagues who are more professionally experienced [to do TR]." (P4) \\
\hline & No support or incentives are available. & 8 & $\begin{array}{l}\text { "We could have been motivated and encouraged [to do TR] [...] it provided it had been presented } \\
\text { more attractively." (P30) }\end{array}$ \\
\hline & & & $\begin{array}{l}\text { "When something is expected to be done voluntarily, this may affect participation negatively }[\ldots] \\
\text { there are things that need to be compulsory [like PD activities]". (P4) }\end{array}$ \\
\hline & $\begin{array}{l}\text { I have to follow the prescribed official curriculum } \\
\text { strictly. }\end{array}$ & 7 & $\begin{array}{l}\text { "I think it [TR] is a good activity if you have enough time, but with a heavy workload, it is really } \\
\text { difficult to do them all, to do research and follow the pacing at the same time." (P23) }\end{array}$ \\
\hline \multirow{5}{*}{$\begin{array}{l}\text { Limitations in } \\
\text { instructors' } \\
\text { awareness, beliefs, } \\
\text { skills and } \\
\text { knowledge }\end{array}$} & I prefer other PD activities. & 7 & $\begin{array}{l}\text { "Of course, when there is a seminar, I attend it. I participated in peer observations and follow-up } \\
\text { feedback sessions. I do these." (P4) }\end{array}$ \\
\hline & $\begin{array}{l}\text { I don't have enough skills and knowledge to do and } \\
\text { disseminate research. }\end{array}$ & 7 & $\begin{array}{l}\text { "[...] I don't know much about TR. I need to learn. Except for that, I don't have any other barriers [to } \\
\text { TR]". (P4) }\end{array}$ \\
\hline & & & $\begin{array}{l}\text { "A systematic inquiry is too formal. It has too many components. This deters me. I think it is } \\
\text { impractical and time-consuming. In the end, you need to do a lot of paperwork, and involve other } \\
\text { people so you need their consent, etc." (P5) }\end{array}$ \\
\hline & $\begin{array}{l}\text { I teach English. I don't do research. It is not my job to } \\
\text { do research. I am not an academic. }\end{array}$ & 2 & $\begin{array}{l}\text { "Because of its impractical nature, I think it is time-consuming. If a teacher needs it, she can do } \\
\text { something like this, but it doesn't need to be a systematic inquiry. We already do this kind of things at } \\
\text { the end of each lesson." (P5) }\end{array}$ \\
\hline & $\begin{array}{l}\text { I don't want to waste my time doing research instead of } \\
\text { sparing it to my students. }\end{array}$ & 2 & $\begin{array}{l}\text { "If there are many studies on it, I don't need to do the same thing again. You can read those and } \\
\text { decide what to do [to apply or not to apply it]. You don't need to reinvent the wheel." (P5) }\end{array}$ \\
\hline \multirow[t]{3}{*}{ Economic matters } & I have to teach for many hours. & 12 & $\begin{array}{l}\text { "My teaching schedule is tight enough. It could have been nice to do something like this, but I need to } \\
\text { have fewer class hours. Under these circumstances, it is not sensible." (P10) }\end{array}$ \\
\hline & $\begin{array}{l}\text { I don't have enough time for TR because I must do a } \\
\text { second job to earn a living. }\end{array}$ & 9 & $---* *$ \\
\hline & Doing research doesn't help me earn extra money. & 3 & $\begin{array}{l}\text { "If we were paid for doing research, I would and also, I believe many colleagues would love to do } \\
\text { research." (P5) }\end{array}$ \\
\hline
\end{tabular}

*Only the high-frequency items are included in the table since Q1 involves 19 items.

** Unfortunately, nothing is mentioned related to second jobs (translations, tutoring, etc.) done to earn a living. It is estimated that this is because doing a job to earn extra money is done -illegally- without paying taxes and confidentially. 
Table 5. (Perceived) Sustained impact of TR based on quantitative and qualitative data

\begin{tabular}{|c|c|c|c|c|c|c|}
\hline \multirow[b]{2}{*}{ Q2 items } & \multicolumn{5}{|c|}{ Frequency } & \multirow[b]{2}{*}{ Quotes from interviews } \\
\hline & 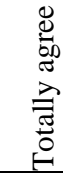 & 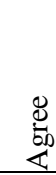 & $\stackrel{\pi}{\overrightarrow{0}}$ & 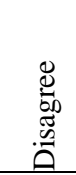 & 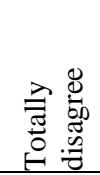 & \\
\hline $\begin{array}{l}\text { I have become more reflective, } \\
\text { critical, student-centred, and } \\
\text { analytic about my practices in class. }\end{array}$ & 4 & & & & & $\begin{array}{l}\text { "Those days [for TR project) I tried really hard to make my students much more active in class. I did this on purpose } \\
\text { Despite this most of my students told me that I was much more active than them. I can never forget this. I remember } \\
\text { this in every lesson. It is not what you believe that matters. I always keep this in my mind and try to pacify myself.' } \\
\text { (P1) }\end{array}$ \\
\hline $\begin{array}{l}\text { I am more confident about my } \\
\text { practices in class. }\end{array}$ & 4 & & & & & $\begin{array}{l}\text { "Sometimes in class, I talk about my research findings. I think they are more convincing both for my students and me } \\
\text { because they came from an academic study supported by the literature. This is a factor that boosts my self-confidence } \\
\text { in class." (P34) }\end{array}$ \\
\hline $\begin{array}{l}\text { I have an increased awareness of } \\
\text { student needs and classroom reality. }\end{array}$ & 4 & & & & & $\begin{array}{l}\text { "I think conducting TR is really important to develop a teacher's awareness because there is a problem detection stage } \\
\text { first of all. You question what is going wrong in your class. Then you try to find solutions and experiment with them } \\
\text { to improve things in your class. This provides teachers with a chance to learn more about students and, of course, a } \\
\text { great way to develop ourselves professionally." (P13) }\end{array}$ \\
\hline $\begin{array}{l}\text { I have improved my teaching } \\
\text { methods and techniques. }\end{array}$ & 2 & 2 & & & & $\begin{array}{l}\text { "In my study, I concluded that correcting students' [...] mistakes immediately had negative and demotivating effects } \\
\text { So, I try to avoid immediate correction in [...] mistakes." (P33) }\end{array}$ \\
\hline $\begin{array}{l}\text { I have improved my researching } \\
\text { skills and now I am more } \\
\text { knowledgeable about doing } \\
\text { research. }\end{array}$ & 2 & 2 & & & & $\begin{array}{l}\text { "Now I am much better at conducting research, analysing data so I feel less anxious about doing research. Now } 1 \\
\text { sometimes think about some issues in my class, and I identify them as good research topics." (P28) }\end{array}$ \\
\hline $\begin{array}{l}\text { I have become aware of the needs } \\
\text { of my colleagues. }\end{array}$ & 2 & 2 & & & & $\begin{array}{l}\text { "I observed } 5 \text { instructors twice and I had a general idea of their possible needs and now I am more aware of the things } \\
\text { they need to develop." (P33) }\end{array}$ \\
\hline $\begin{array}{l}\text { I have improved my theoretical } \\
\text { knowledge on language teaching. }\end{array}$ & 1 & 2 & & 1 & & $\begin{array}{l}\text { "Although I had theoretical knowledge on [...], I didn't know much about error correction in [...] the literature study } 1, \\
\text { did form my TR helped me to improve myself in this area and now when I need help, I go back and read research.' } \\
\text { (P33) }\end{array}$ \\
\hline $\begin{array}{l}\text { I have become more motivated to } \\
\text { develop myself professionally. }\end{array}$ & 1 & 2 & & 1 & & $\begin{array}{l}\text { "I get really motivated when I see that I have achieved something, and my instructional abilities are getting better.' } \\
\text { (P13) }\end{array}$ \\
\hline $\begin{array}{l}\text { I have felt that I can contribute to } \\
\text { my colleagues' professional } \\
\text { development. }\end{array}$ & 1 & 2 & 1 & & & $\begin{array}{l}\text { "We presented our research findings. After my presentation, some of my colleagues thanked me because they told } \\
\text { [me] that they had similar practices to mine, and they always had second thoughts about their practices. They told me } \\
\text { that they felt more relieved." (P28) }\end{array}$ \\
\hline $\begin{array}{l}\text { There is an increase in the success } \\
\text { level of my students. }\end{array}$ & & 1 & 3 & & & $\begin{array}{l}\text { "[my research] subject was the use of [...]: sometimes even students may feel puzzled about this. They may fee } \\
\text { nervous about it. They may question this. At least I can tell them that they shouldn't worry because we do something } \\
\text { that is good for them. It is helpful for them and by doing this I may help them learn better." (P28) }\end{array}$ \\
\hline
\end{tabular}


We found out that participants have become more confident professionals for two main reasons, all of which are also thought to have a positive impact on student success indirectly: (1) They have inquired and examined the effectiveness of certain approaches and classroom practices and now they use these as a basis for their practical action. (2) They feel better equipped to understand and solve class issues as a result of becoming more reflective, student-centred and inquiry oriented. Moreover, participants are more research-oriented (more engaged in and with research, not only TR but also academic research owing to the decision of two of the participants to go on with MA and Ph.D. studies), which is believed to manifest itself in the future teaching practices of the participants and success of their prospective students.

\section{Factors affecting the sustainability of $T R$}

Table 6 illustrates the themes on the factors that facilitate the impact of TR sustain over time and some quotes from interviews.

Table 6. Factors facilitating the sustainability of the impact of TR

\begin{tabular}{|c|c|}
\hline Themes & Quotes from interviews \\
\hline $\begin{array}{l}\text { Positive experience } \\
\text { with TR }\end{array}$ & $\begin{array}{l}\text { "Because my previous study was a success. Personally, I had very good } \\
\text { results in that one." (P28) } \\
\text { "These studies give me the chance to look at my class, students and myself } \\
\text { from a different angle." (P1) }\end{array}$ \\
\hline $\begin{array}{l}\text { TR projects relevant to } \\
\text { participants' } \\
\text { professional goals and } \\
\text { concerns }\end{array}$ & $\begin{array}{l}\text { "Doing research enlightens me about things I am curious about and provides } \\
\text { answers to some issues, in other words, it contributes to my personal } \\
\text { development. We also update our instructional knowledge because we } \\
\text { review the literature for our research." (P28) } \\
\text { "If you question yourself, if you ask yourself why only } 10 \text { out of } 20 \text { students } \\
\text { pass, or why only a few of them use the language, this means that there is a } \\
\text { problem. If there is a problem, you need a solution and this [TR] is one of } \\
\text { the ways to do this." (P1) }\end{array}$ \\
\hline $\begin{array}{l}\text { Dissemination of } \\
\text { research results }\end{array}$ & $\begin{array}{l}\text { "Sharing my research results with my colleagues in academic contexts-I had } \\
\text { a chance to present my findings in three conferences- was really motivating } \\
\text { for me" (P33) } \\
\text { "To be honest, I'd like to do something that is not so complex but something } \\
\text { that useful [...] something that I will be able to share with my colleagues, } \\
\text { show the if it has worked or not." (P16) }\end{array}$ \\
\hline
\end{tabular}

All four participants expressed their willingness to reengage in TR. Nonetheless, they mentioned being withheld from engagement in research by some demotivating factors. The themes related to those factors and related quotes are given in Table 7.

Table 7. Demotivating factors for the sustainability of research efforts

\begin{tabular}{ll}
\hline Themes & Related quotes from interviews \\
\hline 1) Time constraints & "For example, why didn't I do [TR] this year? Because I \\
a) teaching workload & don't have time for it. This is one of the biggest problems. \\
b) administrative responsibilities & We have classes to teach." (P16) \\
c) restrictive \& academic nature of & "I wanted to do [TR] last year[...] just couldn't spare time \\
dissemination methods & for it... maybe because of the tight schedule of [...]. \\
& Because I was working at the [...] Unit, so I couldn't \\
& finish it." (P28) \\
& "[...] I don't like the writing process only. But [I can do \\
& another one] if we are expected to do a presentation or if we \\
& are asked to prepare a less formal written report. But in the \\
& other one, we were prescribed to write according to a strict \\
& outline. So it was a bit stressful for me. The deadline was
\end{tabular}


also stressful." (P1)

2) Lack of support and encouragement "In the future instructors should be recognized more by for TR at school and lack of interest in the administrators [if we are expected to sustain our research efforts]. In school or unit meetings the research findings should be discussed. Maybe our curriculum should be adapted considering those findings." (P33)

3) Lack of expectation for PD at school "Now, let's see how many instructors are engaged in research [she meant 'very few']. Why do the same instructors do it? We don't get anything for this, but we still want to do it, so TR should be a 'must' PD activity because it is very useful for a teacher." (P1)

\section{Discussion}

Even when lots of factors facilitating TR are present in a specific context, teachers will not be engaged in it if they do not have enough time for it (Borg, 2006). Findings revealed that workplace conditions, limitations in instructors' awareness and beliefs about research and economic matters contribute to the most-frequentlymentioned barrier to TR i.e., lack of time. Additionally, Borg (2010) states teachers' socio-economic status may be influential in TR engagement. Likewise, in our study, we determined that having to do second jobs (tutoring, translation, etc.) is a factor that contributes to the restrictions related to time. In this context, the suggestions made by Cochran-Smith and Lytle (1993, p.21) (reduced loads, released time, paid overtime, summer seminars for teachers to reflect on their teaching practices, collaborative networks, research teams and financial support for TR projects) may be applied to increase TR engagement. Correspondingly, Bümen, Ateş, Çakar, Ural and Acar (2012) assert that providing financial support for teachers attending PD activities may be motivating for teachers to engage more in those activities.

Moreover, assigning some administrative and coordinating roles to the instructors within the institution, heavy workload, and having to follow the official curriculum strictly are factors that hinder some participants from engaging in TR. All these are thought to give the participants the idea that what is expected from them in the institution is to fulfil these responsibilities not to engage in TR. This is parallel with what Borg (2006) and Hahs-Vaughn and Yanowitz (2009) highlights. TR is more likely to occur when teachers feel that TR is an activity that they are expected to engage in to be a professional language teacher.

Other factors that hinder participants from engaging in TR are their limited conceptions of research which is based on quantitative and statistical data and strictly outlined academic dissemination methods, which are also acknowledged by other studies (Borg 2006; Gao \& Chow 2012; Rebolledo 2013). Wyatt et al. (2016) state that academic concerns may interrupt TR and an overemphasis on dissemination may be misguiding, discouraging, and intimidating for teachers. Therefore, it is required to present instructor researchers with the particular assumptions underlying TR, its aims, methods, and the expected dissemination methods from them in a way that will not interfere with the main focus of TR, which is understanding and improving instruction (Gao \& Chow, 2012; Rebolledo, 2013; Smith et al., 2014; Wyatt et.al., 2016).

Research shows that the availability of a mentor to provide assistance and support for teacher researchers is valuable (e.g., Borg, 2009; Yuan, Sun \& Teng, 2016). However, in our study context, despite the availability of a mentor and his/her success in 
scaffolding the process for some instructors, some others could not benefit from that mentorship in the same way. Borg (2015b) suggests that besides being authoritative, mentors should be approachable, sensitive to teachers' needs, open to feedback and positive in the way they comment on teachers' work to establish a constructive climate. It is believed that this is possible only when the teachers are also constructive in the manner in which they interact with the mentor. When it is hard to establish a constructive climate between teacher researchers and mentor, it might be a sensible move to get support from instructors with TR experience, because one participant in our study told that s/he got support from her/his colleagues after having failed to get the support from the mentor. Senese (2000) mentions that instructors who have participated in TR projects before can be given roles as facilitators or project leaders. In this way, we not only facilitate novice teacher researchers engage in research without terminating it but also facilitate senior teacher researchers sustain their research efforts in new TR projects.

We consider that the reasons for not engaging in TR may be participants' preference for transmissive models instead of transformative models in Kennedy's (2014) spectrum of CPD models. In other words, it may be hard for instructors to realize the potential of TR and the assumptions underlying it if they perceive themselves as knowledge-consumers instead of knowledge-producers. It is determined that for some participants' research is the job of professional researchers or academicians (Eryllmaz \& Dikilitaş, 2016). Therefore, as it is also stated by Borg (2006), 'Teachers whose conceptions of their own role and research do not extend beyond traditional notions are unlikely to be able to engage in TR productively (p.23).

Findings show that another factor affecting TR engagement is administrative encouragement and support. School culture and administrative reinforcement and support systems for TR engagement are highlighted in many studies (e.g. Borg 2009, 2010; Seider \& Lemma, 2004). Hans-Vaughn and Yanovitz (2009) indicate that administrators are required to provide financial support and release time for PD activities on how to conduct TR and to establish a mentorship programme to facilitate TR. The results of the study coincide with those findings.

The study reveals that the positive effects of TR have been sustained over a four-yearperiod after the finalization of the projects. One of the sustained effects of TR is an increase in professional self-confidence. The reason for this is believed to be the use of strategies proved to be effective in improving students' performance as a result of evidence-based practices. Seider and Lemma (2004) and Akyazı (2016) draw parallel conclusions and they state that participants feel more professional and continue to use the strategies developed throughout their research process. When it comes to the sustainability of TR, Allwright (1997) suggests that what really matter is not engaging in new TR projects but sustaining the research perspective developed in TR process. According to Allwright (1997) with this perspective, an instructor can integrate an investigative element into their context and develop an insight into the reality in their classes. Our findings indicate that this perspective is sustained by the participants, which also corresponds with what Edwards and Burns (2016) suggest about the manifestation of sustained effects of TR in classroom practices in the future. In this way, we believe that it also achieves the ultimate goal of PD mentioned by Guskey (2000), which is an improvement in student success. 
The study indicates that negative experiences with TR have a detrimental effect on the sustainability of research efforts while positive experiences motivate instructors for new projects. Allwright (1997) suggests that difficulties experienced in the research process may result in with the termination of the project and states that 'sustainability is crucial because the adoption of a research perspective (an ongoing concern for understanding) is arguably much more important than the production of one-off research projects, especially if the projects are poorly conducted and lead to burnout' (p. 369-370). The study also indicates that context-related projects with concrete outcomes related to professional goals and class-related concerns positively affect TR engagement and its impact (Borg, 2010; 2015b; Rebolledo, 2013). Therefore, as Borg (2015b) suggests it is a significant requirement for instructors to witness an improvement in classroom practices -and consequently an improvement in student success (Guskey, 2000)- so as to develop a positive attitude towards TR.

\section{Conclusions}

This study offers several contributions to the field of TR engagement and sustainability. First of all, it contributes to the field by providing in-depth data from different study sub-groups in a specific context which will help TR to be adopted by a larger group of ELT instructors and become a sustainable part of the profession. Findings provide insight into the barriers to TR engagement in both personal and administrative levels. Secondly, it enriches the field with the identification of the triggering factors for TR engagement and factors that help the sustainability of TR. Finally, not having come across one before, we think the study may be the first study conducted on the sustained impacts of TR in a specific context in Turkey. Therefore, we also believe that identifying the sustained effects of TR is of great significance for the improvement of student performance in language learning, an area in which the desired proficiency levels cannot be reached in Turkey (British Council, 2015; Çelik et al., 2013).

\section{Implications and future research}

In the SFL in Turkish universities, instead of transmissive modes, transformative PD models (Kennedy, 2014) should be employed so that ELT instructors' awareness, knowledge, and skills related to TR can be improved. Besides, TR should be introduced systematically in a practical and user-friendly form without academic orientation by providing the necessary step-by-step facilitation by mentors. It is observed that in PD units, there is a need for mentors who will play an active role in awareness-raising for TR, providing research skill development and encouragement and moral support systems and facilitation. We also advocate the encouragement of instructors to go on with their post-graduate studies, to disseminate their findings and adopt facilitating roles for novice teacher researchers. Reducing workload, giving released time, paying overtime for TR, arranging summer seminars for teachers to reflect on their teaching practices, establishing collaborative networks, research teams, and providing financial support for TR projects may encourage instructors to engage in TR more. Teachers tend to adopt activities they believe to affect student success levels positively (Guskey, 2000), so dissemination of research results may motivate other instructors to engage in TR.

This study was conducted with a limited number of participants in a specific context. With large-scale survey studies, conditions for TR engagement and sustainability can be 
identified. The identified medium-term sustained effects of TR can be investigated to see if they are sustained in the long term or not. Also, studies on the perceptions of administrators and mentors and studies on the impact of student success can be conducted.

\section{Acknowledgement}

This study was presented at $7^{\text {th }}$ International Congress on Curriculum and Instruction (ICCIEPOK, 2019) in Ankara, Turkey.

\section{Declaration of Conflicting Interests}

The authors declared no potential conflicts of interest concerning the research, authorship, and/or publication of this article.

\section{Funding}

This research did not receive any specific grant from funding agencies in the public, commercial, or not-for-profit sectors.

\section{References}

Ado, K. (2013). Action Research: Professional development to help, support and retain early career teachers. Educational Action Research, 21(2), 131-146.

Akyazı, K.H. (2016). Exploring the impact of teacher research as a form of teacher professional development: A collective case study (Unpublished master thesis). Bahçeşehir University.

Allwright, D. (1997). Quality and sustainability in teacher research. TESOL Quarterly, 31(2), 368-370.

Atay, D. (2008). Teacher research for professional development. ELT Journal, 62(2), 139-147.

Banegas, D., Pavese, A., Velázquez, A., \& Vélez, S. (2013). Teacher professional development through collaborative action research: Impact on foreign Englishlanguage teaching and learning. Educational Action Research, 21(2), 185- 201.

Borg, S. (2006). Conditions for teacher research. English Teaching Forum, 44(4), 2227.

Borg, S. (2007). Research engagement in English language teaching. Teaching and Teacher Education, 23, 731-747.

Borg, S. (2009). English language teachers' conceptions of research. Applied Linguistics, 30(3), 358-388.

Borg, S. (2010). Language teacher research engagement. Language Teaching,43(4), 391-429.

Borg, S. (2015a). Beyond workshop: CPD for English language teachers. In Borg, S.(Ed.), Professional development for English language teachers: perspectives from higher education in Turkey (pp.7-13). Ankara: British Council.

Borg, S. (2015b). Facilitating teacher research: course design, implementation, and evaluation. In Garton, S. \& Richards, K.(Ed.) International Perspectives on Teacher Research (pp. 98-112). doi:10. 1057/9781137376220

Borg, S. \& Sanchez, H.S. (2015). Key issues in doing and supporting language teacher research. In Garton, S. \& Richards, K.(Eds.) International Perspectives on Teacher Research, (pp. 1-13). doi:10. 1057/9781137376220 
British Council. (2015). The state of English in higher education in Turkey: A baseline study. Türkiye Ekonomi Politikaları Araştırma Vakfı \& British Council. Retrieved from https://www.britishcouncil.org.tr/sites/default/files/he baseline study_book_web_-_son.pdf.

Burns, A. \& Edwards, E. (2014). Introducing innovation through action research in an Australian national program: Experiences and insights. In Hayes, D(Ed.), Innovations in the continuing professional development of teachers (pp.65-86). London: British Council.

Bümen, N.T., Ateş, A., Çakar, E., Ural, G. \& Acar, V. (2012). Türkiye bağlamında öğretmenlerin mesleki gelişimi: Sorunlar ve öneriler. [Teachers' professional development in Turkish context: Issues and suggestions] Milli Eğitim [National Education]. 194, 31-49.

Cabaroğlu, N. (2014). Professional development through action research: Impact on self-efficacy. System, 44, 79-88.

Çelik, S., Bayraktar-Çepni, S., İlyas, H. (2013). The need for ongoing professional development: perspectives of Turkish university-level EFL instructors. Procedia-Social and Behavioral Sciences, 70,1860-1871.

Creswell, J.W. \& Plano Clark, V.L. (2018). Designing and conducting mixed methods research. Thousand Oaks, CA: Sage.

Cochran-Smith, M. \& Lytle, S.L. (1993). Inside/outside: Teacher research and knowledge. New York: Teachers College Press.

Dikilitaş, K. (2016). Teacher research as a catalyst for school development. In K. Dikilitaş, M. Wyatt, J. Hanks \& D. Bullock (Eds.) Teachers engaging in research (pp.31-46). Kent: IETEFL ReSIG.

Dikilitaş, K., Smith, R., Trotman, W. (Ed.) (2015). Teacher-researchers in action. Faversham, Kent: IATEFL

Dikilitaş, K, Wyatt, M., Hanks, J. \& Bullock, D. (Ed.) (2016). Teachers engaging in research. UK: IETEFL.

Edwards, E. (2016). The impact of action research on teachers' continuous professional development. ELT Research, 31, 3-6.

Edwards, E \& Burns, A. (2016). Language teacher action research: Achieving sustainability. ELT Journal, 70(1), 6-15.

Eryılmaz, R. \& Dikilitaş, K. (2016). English language teacher's research reticence: A collective case study. TÖMER, 16(7), 15-29.

Fullan, M. (2006). The future of educational change: System thinkers in action. Journal of Educational Change, 7, 113-122.doi:10.1007/s10833-006-9003-9.

Gao, X., \& Chow, A.W.K. (2012). Primary school English teachers' research engagement. English Language Teaching Journal, 66, 224-232.doi:10.1093/elt/ ccr046

Guskey, T.R. (2000). Evaluating professional development. California: Corwin Press.

Hahs-Vaughn, D.L. \& Yanowitz, K.L. (2009). Who is conducting teacher research? The Journal of Educational Research, 102(6), 415-426.doi:10.3200/ JOER.102.6.415-426

Kayaoğlu, M.N. (2015). Teacher researchers in action research in a heavily centralized education system, Educational Action Research, 23(2),140-161. doi:10.1080/ 09650792.2014 .997260

Kennedy, A. (2014). Understanding continuing professional development: the need for theory to impact on policy and practice. Professional Development in Education.doi:40. 688-697. 10.1080/19415257.2014.955122. 
Kutlay, N. (2013). A survey of English language teachers' views of research. ProcediaSocial and Behavioral Sciences.70, 188 - 206.

Niemi, H. \& Nevgi, A. (2014). Research studies and active learning promoting professional competences in Finnish teacher education. Teaching and Teacher Education. 43, 131-142. doi:10.1016/j.tate.2014.07.006

Patton, M.Q. (1999). Enhancing the quality and credibility of qualitative analysis. Health Sciences Research, 34,1189-1208.

Rebolledo, P. (2013). Exploring action research on a professional development course in Chile. (Unpublished doctoral dissertation). University of Leeds, UK. Retrieved from http://etheses.whiterose.ac.uk/5777/1/ThesisPaula\%20 Rebolledo.pdf

Seider, S.N \& Lemma, P. (2004). Perceived effects of action research on teachers' professional efficacy, inquiry mindsets and the support they received while conducting projects to intervene into student learning, Educational Action Research,12(2), 219-238.

Senese, J. C. (2000). What are the conditions that sustain teacher research? Proceeding in the American Education Research Association meeting in New Orleans, USA. Retrieved from http://resources.educ. queensu.ca/ar/aera2000/senese.pdf

Smith, R., Connelly, T., \& Rebolledo, P. (2014). Teacher-research as continuing professional development: A project with Chilean secondary school teachers. In D. Hayes (Ed.), Innovations in the continuing professional development of teachers (pp.111-128). London: British Council. Retrieved from https://www.researchgate.net/publication/309616560

Strauss, A., \& Corbin, J. M. (1990). Basics of qualitative research: Grounded theory procedures and techniques. Sage Publications, Inc.

Trotman, W. (2015). Researching the researchers: A case study of perceptions and reflections of teacher researchers in a higher education context in Turkey. In K. Dikilitaş, R. Smith, Trotman, W.(Eds.) Teacher-researchers in Action (pp. 419429). Kent: IETEFL.

Wang, Q. \& Zhang, H. (2014). Promoting teacher autonomy through university-school collaborative action research. Language Teaching Research, 18(2), 222-241.

Wyatt, M. \& Dikilitaş, K. (2015). English language teachers becoming more efficacious through research engagement at their Turkish university. Educational Action Research, 24(4), 550-570.doi:10.1080/09650792.2015.1076731.

Yuan R. \& Lee, I. (2014). Action research facilitated by university-school collaboration. ELT Journal, 69(1), 1-10.doi:10.1093/elt/ccu031

Yuan, R., Sun, P. \& Teng, L. (2016). Understanding language teachers' motivations towards research. TESOL Quarterly, 50(1), 220-234.doi:10.1002/tesq.279 